\title{
Consumers - global citizens from the CSR 2.0 perspective
}

\author{
Hana Mat'ová1,*, Miroslava Triznová ${ }^{1}$, Vladislav Kaputa ${ }^{1}$, Mikuláš Šupín ${ }^{1}$, Eva Drličková1, \\ Martina Krahulcová ${ }^{1}$ \\ ${ }^{1}$ Technical University in Zvolen, Faculty of Wood Sciences and Technology, T. G. Masaryka 24, 960 \\ 53 Zvolen, Slovak Republic
}

\begin{abstract}
The article focuses on CSR 2.0 concept (Corporate Sustainability and Responsibility) in context with concept of a circular economy and responsible consumer. The main goal of CSR 2.0 is an improvement of the quality of life for all people in the world. This concept perceives consumers as global citizens. The basic principles of CSR 2.0 are Creativity (C), Scalability (S), Responsiveness (R), Glocality (2) and Circularity (0). The companies which implement CSR 2.0 can bring innovative solutions to most pressing social, environmental and ethical problems and challenges in the world. Responsible and conscious consumers can engage in the process of implementing CSR 2.0 by their willingness to collaborate and participate in the marketplace and corporate world. The aim of this paper is to look at the consumer from the "Glocality and Circularity perspective" according to the basic principles of CSR 2.0 in the condition of the Slovak Republic. To fulfil this aim, we conducted a survey of 1061 Slovak inhabitants. The results show the profile of our respondents according to their local actions (environmental actions, buying ethical products etc.) and their profile/activities regarding their participation on circularity (e.g. recycling, re-using, sharing etc.).
\end{abstract}

\section{Introduction}

The general idea that the acts of companies have a strong effect on society is not a new one. The concept of responsibility was developing throughout the centuries.

\subsection{Companies and CSR Concept}

In the beginning of the century growing industrialisation and labour unions brought a concept that aimed at employees and improving their life quality. By the ' 20 s and ' 30 s balancing the profit of the company on one side, and demands of clients, employees and community on the other side, became important for business managers [1]. The following years' first academic definition of the Corporate Social Responsibility appeared. However, practical implementation was aimed mostly at philanthropic activities [1]. By the end of the '60s, strong social pressure on corporations included environmental responsibility in CSR business

\footnotetext{
*Corresponding author: matova@tuzvo.sk
} 
concept. The following thirty years, we can find in scholars, rising awareness of the environmental problems, product safety, and pressure of international organisations, which shifted the theoretical CSR concept to concept, that companies should implement [2]. The late '90s came with the idea that corporate framework should balance companies social, economic and environmental impact [3]. In the 2000's and following ten years authors are calling more for strategic necessity. New concepts for CSR like Corporate Social Performance [4]; and Strategic CSR [5] are appearing. Since then the term Strategic CSR or SCSR is present in scholars. In 2010s the idea of shared value, is appearing among authors [6] and the concept of CSR 2.0 is present in scholars more frequently. CSR 2.0 focus on creating value by the active engagement of both internal and external stakeholders. The value creation is rooted in win-win outcomes for business and society. There is believe that meanwhile companies perform profit-making activities, they are capable to behave as socially and environmentally responsible citizen [7, p.12].

\subsubsection{Responsible company}

The general ideas on CSR were practically reflected in business models like CSR Pyramid [8], model on sustainable development [9] and model CSR 2.0, which based on the following five principles [10,11]: 1) Creativity - that is used in business to solve world social and environmental problems, 2) Scalability - responsible business should continue and go to scale, 3) Responsiveness - continual interaction of business with environment, 4) Glocality - companies have to be aware of local and global context of their actions "Think global, act local“, and 5) Circularity - includes continuous renewal of the resources, and renewal community and employee wellbeing $[11,12]$. This model views a company as a global citizen participating in the global market. It is based on continuous interaction of companies on the supply market side, and consumers on the demand side.

\subsubsection{Responsible consumer}

The effort of the companies to act responsibly toward communities and environment is not possible without the active participation of the consumer.

As for the companies, there are also "R frameworks" for sustainable consumer behaviour: 1 . Recycle - separate items at home, 2 . Reduce - buy only what they need, reduce products with less packaging, 3. Refuse - don't create waste, decline your consumption, 4. Reuse/Repair - extend items products life cycle, 5. Rethink/Reinvent - consider the consumption of the product, 6 . Replace/Rebuy - products with eco-materials or certification [13].

\subsection{Global citizenship}

The well-known "think global, act local" is becoming more popular among consumers [14]. It could be the answer to mutual conscious cooperation between companies and consumers. Becoming a global citizen is conscious and transformative learning. It needs to be accepted, developed and practised [15]. Global citizens are characterised as ones who are acting responsible, caring, and promoting social justice and sustainability [16]. Their values can predict how they identify themselves with a group (e. g. norms, values, behaviours) [17]. The six clusters of the values predicted to be global citizenship identification according to Reysen and Katzarska-Miller [18] are: 1. intergroup empathy (felt connection to individuals outside one's ingroup), 2. valuing diversity (positive view of cultural diversity), 3. social justice (endorsement of human rights and equality), 4. environmental sustainability (concern for the natural environment), 5. intergroup helping (desire to help others outside one's in-group), and 6 . felt responsibility to act for the better of the world. To grow as the personal self and 
professional self, that is connected to all other people around, is basic requirement to become a global citizen [19].

Nowadays, CSR needs a business framework, that combines principles of sustainability, shared value and responsibility for the world based on mutual cooperation [20]. Both consumers and companies need to act responsibly. This could be seen as a shift from CSR to CSR 2.0, the shift from shared value to integrated value, which looks for synergies between social, economic, human and technological values [21, 2]. This mutual responsibility leads into mutual value exchange and supports a circular economy. It leads to sustainability on both supply and demand side of the market.

The main objective of the paper is to assess, whether a Slovak consumer is ready to act responsibly and to be marked as a global citizen as well as to help companies understand the necessity to shift to CSR 2.0. We look at a consumer from the perspective of "Glocality and Circularity" according to the basic principles of CSR 2.0 in the condition of the Slovak Republic.

\section{Methods}

To fulfil the aim of this study, a survey was conducted among 1061 Slovak inhabitants. Data from the buyers of consumer goods were collected from January to February 2018 using an electronic form of the questionnaire distributed via e-mails and social networks in Slovakia. The responses from 1061 Slovak consumers older than 18 years, were collected and analysed. The non-probability sampling method was used - a snowball sampling technique. The kMeans and EM algorithms in the Generalized EM and k-Means Cluster Analysis module of the STATISTICA 12 software were used in the cluster analysis. For the distance measure, a Squared Euclidean measure was used. We analysed 29 items from the questionnaire. Eleven items represent the dimension „Circularity“ and sixteen items represent the dimension „Glocality“. Two items reflected the Responsibility. The questions dealt with i) decisionmaking process for buying consumer goods, ii) green products buying process, iii) factors which influence buying process of consumer goods, iiii) general environmental behaviour and iiiii) green habits of the respondents. Finally, 29 items were selected. The questions were measured on a scale from 1 (definitely yes/YES!), 2 (yes/YES), 3 (neither yes nor no/NEU), 4 (no/NO) and 5 (definitely no/NO!).

\section{Results}

As Visser [11, p. 13] stated: "Self-selecting ethical consumers will become irrelevant, as CSR 2.0 companies begin to choice-edit, i.e. cease offering implicitly 'less ethical' product ranges, thus allowing guilt-free shopping. Post-use liability for products will become obsolete, as the service-lease and takeback economy goes mainstream." This thought led us to conduct this study. Until CSR 2.0 will be implemented in practice of the companies all around the world, the consumers need to act in a responsible and conscious way as much as possible. Consumers have to make effort and push the companies to act in a responsible and conscious way. It means, consumers have to require from companies: adopting circular economy principles into practice. Consumers have to demand from companies developing products and processes that will not pose a threat to the environment, society and future generations.

The results of the cluster analysis are three groups of respondents (see Table 1). Table 1 represents the modes for each item from three dimensions - Circularity, Responsibility and Glocality.

As the most responsible and conscious consumers seem to be in the cluster $3(33.27 \%)$. They agreed with 20 statements and they had a neutral attitude towards 9 statements. They positively reacted to 9 items from dimension "circularity" and they had neutral attitudes only 
towards the two items: "I am looking for ways, how to reuse products (for example, make them decorations, etc.) - Reuse"; "I try to buy products in second-hand shops, bazaar "Reuse. So, we can say, that they are acting somehow in a responsible way - reusing, recycling, reducing, sharing, repairing and they are an active part of the circular economy. As for dimension "Glocality" - act local think global, they expressed a positive attitude towards nine items and neutral attitudes towards seven items (see Table 1). Overall, this group of respondents is interesting because they did not express any negative attitudes at all and this fact is rather striking.

In contrast to the third group, we list the group of respondents from the cluster 2 . The least responsible and conscious respondents in the sample were in the Group $2(22.71 \%)$. They expressed 15 negative attitudes, six neutral attitudes and only eight positive attitudes to the statements. They expressed negative attitudes towards five items from dimension "Circularity" and ten from dimension "Glocality". Respondents expressed strong agreement with only the two statements from "Glocality" dimension: "I try to drink tap water and not to buy bottled water in plastic bottles" and "I try to buy new products only if it is not possible to repair the one, I have in my household" (item N.15). The respondents from this cluster expressed a positive attitude towards 2 items from "Circularity" - "I try to use the products as long as they fulfil their purpose" - Reuse/repair (item N.2) and "If possible, I try to fix things (or let them fix by others), for example: clothing, electronics)" - Reuse/Repair (item N. 6) and these two statements correspond with the above-mentioned statement (item N.15) from dimension "Glocality".

They also expressed strong agreement with the following statement from dimension "Responsibility": "I think, that environmental issues and problems should be solved primarily by state, then by corporations (enterprises, companies)" and neutral attitude toward: "I can contribute to solving environmental problems, through my personal decisions about purchasing environmentally friendly products." Moreover, they expressed a negative attitude (as the only one from our clusters) toward statement from dimension "Glocality": "I try to encourage people around me, to protect the environment". According to the above mentioned, they seem to be sceptical or do not believe, that they can contribute (as an ordinary human being or citizen) to the improvement of the state of the environment and society. Probably, they consider the state/government and the corporations as those who are primarily responsible to solve these issues. The positive is, that they expressed only six neutral opinions overall.

The last group (cluster 1) consists of 467 respondents (44.01\%) and they expressed 13 positive, 11 neutral and five negative attitudes towards items from the questionnaire. They expressed the neutral attitude towards ten statements and also, they expressed the three positive and the three negative attitudes towards statements from "Glocality". As for dimension "Circularity" they had a positive attitude towards eight statements and comparing to the cluster 1 (nine positive attitudes from eleven), the differences are in the three statements (N. 5, 9 and 11 - see Table 1). In the items N.5 and 9 the respondents from cluster 1 expressed the negative attitude unlike the respondents from cluster 3 who expressed neutral opinions. It seems, that respondents from this cluster 1 (about 44\%) could represent the "average consumer" who has good knowledge of how to reduce, reuse, repair, recycle etc. But this consumer is cautious and not yet convinced that local actions may affect global events. 
Table 1. Results of cluster analysis.

\begin{tabular}{|c|c|c|c|c|}
\hline \multicolumn{2}{|r|}{ Items from dimension CIRCULARITY } & C 1 & $\mathbf{C 2}$ & C 3 \\
\hline 1 & I try to sort and recycle waste - Recycle & YES & YES! & YES! \\
\hline 2 & $\begin{array}{l}\text { I try to use the products as long as they fulfil their purpose - } \\
\text { Reuse/repair }\end{array}$ & YES! & YES! & YES! \\
\hline 3 & $\begin{array}{l}\text { I donate products that I do not use (e.g. clothes) to friends, family, } \\
\text { charity instead of throwing them into a trash - Reuse, sharing }\end{array}$ & YES! & YES! & YES! \\
\hline 4 & If possible, I separate waste (at home, at work, etc.) - Recycle & YES & NEU & YES! \\
\hline 5 & $\begin{array}{l}\text { I am looking for ways, how to reuse products (for example, make them } \\
\text { decorations, etc.) - Reuse }\end{array}$ & NO & NO! & NEU \\
\hline 6 & $\begin{array}{l}\text { If possible, I try to fix things (or let them fix by others), for example. } \\
\text { clothing, electronics) - Reuse/Repair }\end{array}$ & YES & YES & YES \\
\hline 7 & $\begin{array}{l}\text { I take used batteries, incandescent lamps, broken electrical appliances, } \\
\text { to garbage collector places or I make sure, they get there. - Recycle }\end{array}$ & YES & NO! & YES! \\
\hline 8 & $\begin{array}{l}\text { I do not waste food, and I always try to use all food products I bought. } \\
\text {-Reduce }\end{array}$ & YES & YES! & YES! \\
\hline 9 & I try to buy products in second hands shops, bazaars - Reuse & NO & NO! & NEU \\
\hline 10 & $\begin{array}{l}\text { I save resources (water, electricity) due to environmental impacts. - } \\
\text { Reduce }\end{array}$ & YES & NO & YES! \\
\hline 11 & I buy products made from recycled materials - Replace/Rebuy. & NEU & NO & YES \\
\hline \multicolumn{5}{|c|}{ Items from dimension RESPONSIBILITY } \\
\hline 12 & $\begin{array}{l}\text { I think, that environmental issues and problems should be solved } \\
\text { primary by state, then by corporations (enterprises, companies). }\end{array}$ & YES & YES! & YES! \\
\hline 13 & $\begin{array}{l}\text { I can contribute to solving environmental problems, through my } \\
\text { personal decisions about purchasing environmentally friendly } \\
\text { products. }\end{array}$ & YES & NEU & YES! \\
\hline \multicolumn{5}{|c|}{$\begin{array}{l}\text { Items from dimension GLOCALITY } \\
\end{array}$} \\
\hline 14 & I try to drink tap water and not to buy bottled water in plastic bottles. & YES! & YES! & YES! \\
\hline 15 & $\begin{array}{l}\text { I try to buy new products only if it is not possible to repair the one, I } \\
\text { have in my household. }\end{array}$ & YES & YES! & YES! \\
\hline 16 & I try to encourage people around me, to protect the environment. & NEU & $\mathrm{NO}$ & YES! \\
\hline 17 & $\begin{array}{c}\text { I buy products, which were made ethically (eg produced in accordance } \\
\text { with the employees' rights, produced without adverse effects on the } \\
\text { environment or human health, etc.). }\end{array}$ & NEU & NEU & YES \\
\hline 18 & $\begin{array}{l}\text { I actively search for information about companies, businesses, and } \\
\text { their behaviour (e.g., environmental, social behaviour, etc.). }\end{array}$ & NO & NO! & NEU \\
\hline 19 & $\begin{array}{c}\text { My purchase decision is affecting by: if the product has any } \\
\text { environmental (or social) labelling }\end{array}$ & NEU & NEU & YES \\
\hline 20 & $\begin{array}{l}\text { My purchase decision is affecting by: if buying a product is } \\
\text { contributing to a good thing (e.g. is supporting local producers) }\end{array}$ & YES & NEU & YES! \\
\hline 21 & I'll pick up garbage from the ground, even though they are not mine. & NEU & $\mathrm{NO}$ & NEU \\
\hline 22 & If possible, I buy products in reusable, or recyclable packaging. & NEU & $\mathrm{NO}$ & YES \\
\hline 23 & $\begin{array}{l}\text { I buy foods, detergents, personal cosmetics in an e-shop or in a store } \\
\text { that offers organic and ethical products. }\end{array}$ & NO & NO! & NEU \\
\hline 24 & I buy products from local producers. & NEU & NEU & YES \\
\hline 25 & I buy FAIRTRADE products. & NEU & NO! & NEU \\
\hline 26 & I buy products (e.g. furniture, paper), certificated by FSC, PEFC. & NEU & NO & NEU \\
\hline 27 & I boycott some products and brands (e.g., animal-tested cosmetics). & NEU & NO! & NEU \\
\hline 28 & I buy products labelled as BIO or green food & NEU & NO & NEU \\
\hline 29 & I take to the pharmacy all medicines, that after the warranty period. & NO! & NO! & YES! \\
\hline \multirow{2}{*}{\multicolumn{2}{|c|}{$\begin{array}{c}\text { Number of cases } \\
\text { Percentage }(\%)\end{array}$}} & 467 & 241 & 353 \\
\hline & & 44.01 & 22.71 & 33.27 \\
\hline
\end{tabular}


In the cluster 1 (average consumers), there is circa $60 \%$ women, more than $80 \%$ of respondents are 18-39 years old and more than $90 \%$ of respondents have secondary education leaving exam and higher. In the cluster 2 (the sceptical cluster), there is circa $52 \%$ of women and $48 \%$ of men, nearly $58 \%$ are $18-29$ years old and circa $18 \%$ are 50 and more years old. In this cluster, $21.99 \%$ of respondents have primary or secondary education without leaving exam and only almost $27 \%$ with university education (the highest representation of people with lower education among clusters). The cluster 3 (the most responsible), there is almost $70 \%$ of women (the highest percentage among clusters). As for age, we can see that more than one third is $18-29$ years old and more than one quarter is 50 and more years old (the highest percentage among clusters), more than $87 \%$ of respondents have secondary education with leaving exam and higher education.

We also asked respondents whether they know what the following three terms mean "zero waste", "slow fashion" and "slow food". Respondents from cluster 1 (average consumers) - more than $60 \%$ don't know the term "zero waste", more than $49 \%$ don't know the term "slow fashion" and more than $68 \%$ don't know the term "slow food". As for cluster 2 (sceptical consumers), nearly $80 \%$ don't know the term "slow food", more than $76 \%$ don't know the term "zero waste" and almost $65 \%$ don't know the term "slow fashion". Cluster 3 (the most responsible), more than 60\% know the term "slow fashion" but almost $57 \%$ don't know the term " slow food" and nearly 50\% know the term "zero waste". These results correspond with the characteristic features of the clusters which were mentioned above (see table 1). In sum, the most responsible consumers from cluster 3 demonstrated the highest knowledge of these terms while the respondents from the cluster 2 (sceptical consumers) demonstrated the lowest knowledge of these terms.

\section{Discussion and conclusion}

In our paper, we described consumers from "Circularity" and "Glocality" perspective which are the two basic principles of CSR 2.0. and deemed them as global citizens. We agree with Ricci, Marinelli and Puliti [22, p. 397] who stated: "The consumer as a citizen is someone who makes purchasing choice in respect of the sustainable development of the world community. Environmental protection, social responsibility, labour security become his main criteria leading the act of buying ". As citizens, we have not only the rights but also the duties and we are responsible for our own actions. Ricci, Marinelli and Puliti [22, p. 395] introduced the idea that the responsibility of consumer is the foundation of Corporate Social Responsibility (CSR). Moreover, a global citizen is someone who is aware of and understands the wider world - and their place in it. Global citizens take an active role in their community, and work with others to make our planet more equal, fair and sustainable [23]. That's why we looked at respondents as global citizens and describe them from this perspective. Facing recent global changes, we are not just spectators of this "theatre", we are part of it, we are actors. We all are connected, and we have to be aware that every small act can have global consequences, every personal act can influence the state of the whole society. If companies decide to implement the principles of CSR 2.0, they will need partners -ethical consumers behaving in environmentally conscious manner. Ricci, Marinelli, and Puliti [22, p. 400) mentioned that "ethics could be considered as a bridge between production and consumption". Approximately $60 \%$ of respondents strongly agree that primary state/government and then corporation/companies should solve the environmental issues. Some studies $[24,25]$ introduced that companies as well as public authorities can incorporate requirements for certified products into their green (sustainable) procurement policies. Sustainable procurement is dealing with the concept of social responsibility and good corporate citizenship. 
To conclude the results of our research: we identified the three main clusters of consumers in Slovakia. According to results each cluster has a different level of engagement in the pre-purchase phase, purchase and using phase, and post-purchase phase. The most active in mutual cooperation could be the cluster C3. Thus, we see the following main areas for their engagement: they are active in Circularity and Glocality. In the term of Circularity: they are active recycling and reusing materials, food and products in households; they actively participate out of their group, willing to make an effort to contribute to a better global world by recycling, taking used items to collect spots; they see companies, and themselves as partners who are equally responsible for the global world. In term of Glocality: they consciously think about their purchases; they purchase items that are contributing to "a good thing”, have ecological or social labelling; they support local producers. This group is also strong evangelist among other peers, tend to encourage people to protect the environment.

These characteristics could help companies to set better communication with targeted cluster when levelling up to CSR 2.0. It can also help companies do identify areas for mutual cooperation with consumers, to participate actively in "Circularity and Glocality". It provides companies with information about areas, in which are consumers already engaged and can promote this area among other clusters - less active consumers (C 2 and $\mathrm{C} 3$ ).

As Visser [11, p. 9] stated: "companies that embrace the CSR 2.0 era will be those that collaboratively find innovative ways to tackle our global challenges and be rewarded in the marketplace as a result". Therefore, in the future, it is important to focus on the barriers of the innovative capacities for the development of ecological innovation at all levels of the innovation system [14]. Ethical, responsible, and conscious consumers acting as global citizens reward such companies because they are aware that everything all around us is connected. They perceive themselves as a part of the circle or we may say, as a part of the sustainable and responsible business model. The shared ethics is a bridge which connects two worlds: the world of consumers and the world of producers, the demand and supply side of the market.

This paper is an output of the science project number 1/0666/19 "Determination of the development of a wood-based bioeconomy" and grant number 1/0674/19, "Proposal of a model for the eco-innovation integration into the innovation process of companies in Slovakia in order to increase their performance", and "European Network for Environmental Citizenship" COST action CA 16229.

\section{References}

1. A.B. Carroll, A history of corporate social responsibility: concepts and practices. (New York: Oxford University Press, 2008)

2. M.A.L. Agudelo, L. Jóhannsdóttir, B. Davídsdóttir, A literature review of the history and evolution of corporate social responsibility. International Journal of Corporate Social Responsibility 4, 1 (2019)

3. J. Elkington., Partnerships from cannibals with forks: The triple bottom line of 21stcentury business. Environmental Quality Management 8, 37-51 (1998)

4. H. Wang, J. Choi, A new look at the corporate social-financial performance relationship the moderating roles of temporal and interdomain consistency in corporate social performance. Journal of Management 39, 416-441 (2013)

5. A. McWilliams, D. S. Siegel, P.M. Wright, Corporate social responsibility: Strategic implications. Journal of management studies 43, 1-18 (2006)

6. M. R. Kramer, M. Porter, Creating shared value. Harvard Business Review 89, 62-77 (2011). 
7. M. A. Camilleri, CSR2.0: A Conceptual Framework for Corporate Sustainability and Responsibility. Gower Publishing (Forthcoming 2016).

8. A. B. Carroll, Managing ethically with global stakeholders: A present and future challenge. Academy of Management Executive 18, 114-120 (2004).

9. G. Aras, D. Crowther, The durable corporation: Strategies for sustainable development (Routledge 2016).

10. W. Visser, The New Era of Corporate Sustainability and Responsibility. CSR Inspiration Series No. 1. Published online by CSR International. http://www.csrinternational.org (access: 20.04.2016) (2008)

11. W. Visser, The future of CSR: Towards transformative CSR, or CSR 2.0. Kaleidoscope Futures Paper Series 1, 1-17 (2012).

12. K. Raczkowski, Ł. Sułkowski, J. Fijałkowska, Comparative Critical Review On Corporate Social Responsibility. International Journal of Contemporary Management 15, 123-150 (2016).

13. S. J. Alatervo, The 6 Rs: making a sustainable impact. Available at: https://prosperouswaydown.com/6rs-making-sustainable-impact/. (Accessed July 10, 2019) (2013)

14. E. Loučanová, M. Olšiaková, E. Drličková, Regional marketing and business in context "Act locally, think globally". Globalization and its socio-economic consequences: proceedings p. 681-687 [online] (2018)

15. A. A. Robinson, L. Levac, Transformative learning in developing as an engaged global citizen. Journal of Transformative Education 16, 108-129 (2018)

16. S. Reysen, L. W. Larey, I. Katzarska-Miller, College course curriculum and global citizenship. International Journal of Development Education and Global Learning 4, 27-40 (2012)

17. J. C. Turner, M. A. Hogg, P. J. Oakes, S. D. Reicher, M. S. Wetherell, Rediscovering the social group: A self-categorization theory (Basil Blackwell, Oxford, 1987)

18. S. Reysen, I. Katzarska-Miller, A model of global citizenship: Antecedents and outcomes. International Journal of Psychology 48, 858-870 (2013)

19. W. Rosa, H. K. Shaw, Global nurse citizenship: Toward a safe and inclusive civil society. (Springer, New York, 2017).

20. J. Elkington, 25 years ago I coined the phrase "triple bottom line." Here's why it's time to rethink it. Harvard Business Review (2018).

21. W. Visser, W. Integrated Value vs. Shared Value and CSR 2.0. AMS Sustainable Transformation Briefing Series, No. 5, Antwerp: Antwerp Management School, (2018)

22. C. Ricci, N. Marinelli, L. Puliti, The consumer as citizen: the role of ethics for a sustainable consumption. Agriculture and agricultural science procedia 8, 395-401 (2016).

23. Oxfam. Curriculum for global citizenship [online]. Available at: http://www.oxfam.org.uk/coolplanet/teachers/globciti/globciti.htm. [Accessed July 10, 2019]

24. N. Slašt’anová, M. Krahulcová, H. Paluš, T. Čorejová, A. Križanová. Application of Green Purchasing Behaviour in Companies. Economics, Management and Technology in Enterprises 2019 (EMT 2019). Atlantis Press 78, 102-106 (2019)

25. H. Paluš, J. Parobek, R. Šulek, J. Lichý, J. Šálka. Understanding sustainable forest management certification in Slovakia: forest owners' perception of expectations, benefits and problems. Sustainability - BASEL 10, 17 (2018) 